\title{
Transmutation and Temporality: Shifting Figures of African Women in Jennifer Makumbi's Historical Novel Kintu (2014)
}

\author{
Mr. Jeremiah M. Muneeni1 ${ }^{\text {ID }} \bigotimes$, Dr. Esther K. Mbithi ${ }^{2}$, and Dr. Justus K. S. Makokha ${ }^{3}$ \\ ${ }^{123}$ Department of Literature, Linguistics and Foreign Languages, Kenyatta University, Nairobi, Kenya \\ $\triangle$ Corresponding Author: Mr. Jeremiah M. Muneeni, E-mail: muneeni.jeremiah@ku.ac.ke
}

ARTICLE INFORMATION ABSTRACT

Received: December 17, 2020

Accepted: February 02, 2021

Volume: 4

Issue: 2

DOI: $10.32996 /$ ijllt.2021.4.2.25

\section{KEYWORDS}

Transmutation, Gender, New historicist, Patriarchy, Feminism
The role of African women writers in employing the unique style of presenting several generations of women characters in the same historical novel to narrate how the world of women has been transformed across time cannot be naysaid. Through this style, female authors have been able to re-examine, re-construct, re-structure and reinvent the (mis)representation of female gender as construed by male authors who were the first to acquire formal education and embark in creative writing. Thus the choice of this distinctive style often serves as an important marker of backdating the true depiction of women across the historical trajectory as well as demonstrating the gainful transmutation that women have gone through towards their liberation from the chains of patriarchy. Among the African women writers who have adopted this style is Jeniffer Makumbi the author of Kintu. Grounded in both New historicist and feminist theoretical frameworks, we interrogate how women have gradually and gainfully changed towards liberation across the four epochs specific to Africa; namely: Pre-colonial, Colonial, postcolonial and contemporary. Using purposively selected Jenniffer Makumbi's novel - Kintu - the article provides a textual analysis of the behaviours, speeches and actions exhibited by different generations of female characters who fall within the aforementioned epochs to demonstrate their historical transmutation towards liberation.

\section{Introduction}

Creative writing does not develop out of a vacuum rather it springs from the author's experiences and or observations from the society in which the author is part. Therefore, the initial men's writing, and later women's writing depicted the society as it was. For a long time, patriarchy had been sanitized in Africa and beyond. Consequently, the writing that emerged from the male authors, especially the earlier ones who had an advantage of starting to write ahead of their female counterparts, seemed to celebrate patriarchy. Though African women authorship followed shortly, Efuru, the first novel by Flora Nwapa, the "mother" of modern African writing was dismissed as "[...] nothing more than idle chatter, chit-chat prittle-prattle, gossip of a woman (Palmer and Jones, 83)" while Things Fall Apart by Chinua Achebe the "father" of modern African literature was celebrated as "the best known writer of fiction and possibly the best known writer of fiction from black Africa" (Doug Killam, 515). It is undeniable that the artistry exhibited by a writer depends on their creative genius and propensity to manipulate language to enable them articulate their concerns effectively. The artistic impress of the two writers may not be at the same level but seemingly, Nwapa's work is dismissed on the basis of her concerns rather than her stylistic impression. Nwapa writes from the viewpoint of an African woman and concerns herself with subjects that pertain to women's concerns. This attitude towards women writing led to exclusion of their works from serious criticism hence furthering their marginalization even when they had joined the male authors in creative writing. It is against their side-lining that the contemporary women writers adopted a new style - of including several generations within the same novel and setting it within a century-long time frame in order to give a candid depiction of the transmutations that have happened across the history of African female fraternity. This paper analyses these changes and how they depict the progressive women emancipation both within and without the fictional world. Jeniffer Makumbi's novel Kintu acts as the main reference point.

K C AL-KINDI CENTER $\mathbf{R}$ D FOR RESEARCH AND R D DEVELOPMENT Your gateway to world-class research

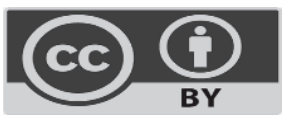

Published by Al-Kindi Center for Research and Development. Copyright (c) the author(s). This open access article is distributed under a Creative Commons Attribution (CC-BY) 4.0 license 


\section{Historicising Women Writing in Africa}

Ever since women creative works started attracting serious criticism, there has emerged several full length books on the interconnection between female gender and literary production in African literature. Notably, most of them are written, edited and or compiled by women who have become conscious of exclusion of their counterparts in the literary arena dominated by patriarchal hegemonic critics. Some full-length books resulting from single authors' comprehensive research include: Katwiwa Mule's Women Spaces, Women's Visions: Politics, Poetics and Resistance in African Women's Drama and Florence Stratton's Contemporary African Literature and Politics of Gender. Others, borne out of combined efforts by a team of researchers include: Daymond, et al. Women Writing Africa: Vol.1 (The Southern Region). Sutherland-Addy et al Women Writing Africa: Vol.2 (West Africa and the Sahel), Lihamba et. al Women Writing Africa: Vol.3 (The Eastern Region), and Sadiqi et. al Women Writing Africa: Vol.4 (The Nothern Region). These books were compiled between 2003 and 2009. They cut across all genres with works produced by women between the $17^{\text {th }}$ century and 2004 being included.

The aforementioned books are backdated corrective studies on account of patriarchy and hegemonic masculine delineations unpacking the production of precolonial and postcolonial literature. They attempt to demonstrate that contemporary African art is laden with history skewed towards male epistemologies of art. By compiling various genres produced by women from various regions many years back in pre-literate Africa, the writers demonstrate that there, indeed, existed a vital contribution by women in African political, psycho-social, economic and human development which is intertwined with historical gender dynamism. They, therefore, attempt to highlight the need for the historical female gender segregation practiced by male writers to be reexamined and made gender inclusive.

To further this cause, contemporary African women creative writers have emerged with a unique style of writing, with several generations of women packaged in the same text and each generation's women characters changing gradually towards attaining autonomy. The setting of the texts cuts across a century-long time frame. I am reading this style as an attempt to backdate the setting of their texts in order to recover time lost when they either had not acquired enough education to enable them to write, or their works had not started enjoying much attention with those that had come out being dismissed as inconsequential women gossip. Their style of women representation can, therefore, be viewed as a correctional attempt on (mis)representation by male writers of the past. The peculiar style, particularly, highlights how women have increasingly changed with time to emerge as probable challengers of patriarchal tendencies, and how gender inclusivity has been re-imagined, re-constructed and maintained.

This unique style of writing is not a preserve for any African region. From East Africa, Jennifer Makumbi's historical novel Kintu and Margaret Ogola's The River and the Source fall under this category. Aminata Forna's Ancestor Stones and Campbell Fatoki's Threads of Gold Beads are borne out of West African experiences. The authors trace four generations of women within their books, a feat that provides an avenue to examine and analyse the female characters' transmutations within a century to highlight the changes. The four generations can thus be categorized as the first, second, third and fourth generations of women. To understand the changes inherent in the female gender fraternity, it is important to analyse each generation against the backdrop of the happenings within and without the fictional world at that time. Due to space constriction, this paper delimits itself to Makumbi's novel - Kintu.

\subsection{The Pre-literacy African Women Epoch: Nnakato}

The African women writers in their endeavour to present an objective account of their foremothers, especially during the precolonial period, did not find it necessary to debunk the myths that portray the pre-literate woman as weak, subdued, and an affiliate of man. The same would amount to an attempt to present a skewed subjective perspective of the existing relationships of the two genders owing to the fact that in as much as there is fiction in writers' works, the fictional works cannot be devoid of nuances from the community in which the work is set.

Patriarchy has socialized women into believing that they belong to the peripheral position. For patriarchy to thrive, a sort of socialization that makes women believe they are weaker, inferior and subject to men had to be inculcated into women's system and be passed from one generation to another. Notably, women, having been cultured to accept their peripheral position in the society, participated in passing the same ideology to fellow women of the next generation without much ado because it had been accepted among them as the norm.

However, with advent of feminism, feminists have come out to question the rationale behind the subaltern position women occupy. They have come out strongly to challenge the tenets of their socialization that have made them to believe they are not equal to their male counterparts. Feminists have preoccupied themselves with bringing to the fore the fact that other than biological roles that are defined and determined by different anatomies of the two genders, the other differences are socially- 
constructed hence they can be successfully challenged and re-constructed to offer equal opportunities to both genders. Solomon Azumarana, while studying the representation of women by Chinua Achebe opines:

Achebe's women characters have been ideologically conditioned that men are biologically superior to women physically; intellectually and emotionally hence women only come and go with mounds of foofoo, pots of water, market baskets, fetch kola, and bear scolding and beatings. (19)

According to Azumarana, the reason why male characters ideologically suppress women is the desire to maintain their control and domination of the economic structure of the society through exercising authority over them.

This kind of socialization is in line with the metaphor used by Sylvia Tamale in her article "When Hens begin to Crow" which indirectly refers to women's realization that the position they occupy is a creation of men. As a result, they start challenging the patriarchal structures. Using the metaphor of the hen in a flock where there are cocks, Tamale observes:

Female chickens normally do not crow. At least popular mythology claims they cannot. Hence, in many African cultures a crowing hen is considered an omen of bad tidings that must be expiated through the immediate slaughter of the offending bird (218).

Tamale uses the hen-cock metaphor to capture the gender interrelationship at the point in history. Metaphorically speaking, the slaughtering of the offending bird referred to here is the aligning of any woman who tries to resist the peripheral position created for women with the socialization guidelines. Thus, there has been no room for resisting this position.

The pre-literate girl child is born with the subaltern position tag on her neck. The pre-literate African society places a lot of importance on the shoulders of the boy child, seemingly, forgetting the girl child. She exists to receive orders and directions from her male counterparts which she is not expected to question. Any deviation from perceived norm of submissiveness is construed as an anomaly on the side of the woman. The inculcation of these gender roles is done both consciously and subconsciously.

In Makumbi's Kintu, Babirye and Nnakato's marriage is decided by their parents without any consultation. When Kintu Kidda decides to go against the dictates of the Ganda community by courting Nnakato ahead of her elder twin sister Babirye, the parents, in an attempt to persuade him to adhere to the edicts of the community in ensuring that the younger sister is not married off ahead of the elder one "[...] offer(s) her for free but Kintu would not have her" (12). These women are socialized into believing that their marriage need not be based on love, rather once they grow up, they can be "sold off" by their father regardless of whether they have any feeling towards the suitor. Although Kintu Kidda marries Babirye later due to barrenness of his preferred wife Nnakato, the circumstances of marriage are the same. The union is not informed by any form of love, rather it is an aspect of necessity dictated by the fact that Nnakato wanted children of her own and the only conduit through which she could get them was through her fertile sister.

Further, when Kintu Kidda establishes himself as the Ppokimo, he marries more women who "[...] were brought to him as tributes: some from ambitious parents, others were daughters of fellow governors" (16). Such women are commodified and given off without considering their emotional attachment to the groom: "His wives' homes were scattered all over the province for his convenience when he toured. The families, especially in far-flung regions of the province, were also a reminder to the populace of his presence" (16). The wives must wait for the husband to be pushed by administrative rather than matrimonial need to visit them. Consequently, meeting their emotional needs as wives is only "fortuitous" when he visits them on his stopovers. Markedly, the Ppokimo uses his wives as human props to mark his territory. Their major purpose in his life is not to have them partake in the bliss of the matrimony but to scare his subjects into acknowledging him as their leader. The women remain docile; they don't realize they are being commodified. The two instances captured by Makumbi point to the fact that the pre-literate women are victims of the patriarchal machination.

The patriarchs create the senior wife position is is used as a blinker for women to make them believe that they are part and parcel of leadership. The reality is, however, that they are leaders without portfolio. Nnakato as a senior wife is not in a position to make any decision on her own. She is directed by Kintu Kidda on what to do with her co-wives.

The narrator points out:

Kintu married other women besides Nnakato. The women were brought to him as tributes: some from ambitious parents, others were daughters of fellow governors. His wives' homes were scattered all over the province for his convenience when he toured. The families, especially in the far-flung regions were also a reminder to the local populace of his presence. Nnakato was in charge of the wives (my emphasis) (16). 
The position seems to give women a feeling of elevation, respect and self-worth. But does it make them deputy designates of their patriarchs? Hanrahan and Antony's argument can be used to attempt to answer this semi - rhetorical question. They posit:

[The] thing that makes the assumption of authority dangerous for women is that it feels transgressive to claim authority. Persons who have been socialized to accept subordinate status may well have internalized the view that they cannot be legitimate authorities in whatever they do, that they have no right to set themselves up as authorities. (76)

Thus Nnakato, despite the enviable position she occupies, does not demonstrate any attempt to arrogate the authority to herself owing to her socialization. She feels that the authority she has is not her own. She can only act on behalf of her husband. Hence she only does as directed, without her own contribution.

Despite the peripheral position, the pre-literate women are not condemned to a hopeless position. Makumbi, in what appears to be a foretelling of women emancipation in future, creates a woman character who successfully delinks herself from the shackles of men's emotionless marriage. Gita, a respectable elder and neighbour to Kintu Kidda marries a relatively young bride; Zaya. On attempting to consummate the marriage, Zaya resists and runs away. Men who narrate to each other what happened offer different opinions as to why Zaya denies her husband the conjugal rights with some saying she was not properly nurtured into accepting her position as a wife while others feel Gitta's first wife should have prepared her until she was ready then handed her over to her designated husband. In a humorous manner, the narrator captures the resistance that he met with:

This particular night, Gitta was to get his dowry's worth. When he got to her quarters, Zaya started the childish game of: Leave me alone, I don't want. Gitta gave her few whacks to let her know that he was serious. Zaya stopped fighting. He made his move but Zaya went wild. She grabbed him - you know how huge she is now - swung him like a fibre doll and ran. Gitta thinking he was the bull he once was gave chase. Zaya ran into shrubbery behind her quarters, Gitta in pursuit. In the darkness, he ran into acacia shrub. Somehow, the stems locked around his neck. When he pulled his neck out, the stem tightened (22).

Gitta does not get to consummate their marriage with Zaya as she eventually ends up in the Ppokimo's home. Women get an opportunity to laugh at Gitta's action christening him "the aged bull that grazes among calves" (23). Though Ppokimo warns his teenage sons against making sexual advances towards her, and requests that they treat her as their sister and respect her as a married woman, the sons, just like everybody else are uneasy with her. They laugh off their fathers warning wondering who wants to have a relationship with:

[...] a pugilistic bride, who took strides like a hunter, whose feet grasped the earth like a man's, whose voice when she spoke, carried the whole house on top of her head and who, as if her mother never breastfed her properly, said that she had dreamed of becoming a warrior (23).

When Zaya is let free in Kintu Kidda's house, she forgets that she is a married woman and joins his sons in laying traps and shooting birds out of trees. The boys keep on reminding her that she is a woman.

Zaya's behaviour may be dismissed as a rare abnormality in female fraternity by men who would vouch for the status quo to be maintained. Nevertheless, Makumbi uses her behaviour which defies the societal established norms to give hope to the oppressed women that their liberation is coming. The acceptance of everything that is thrown to women is challenged by Zaya who foretells the path that the future African women will take.

\subsection{The Permeation of Formal Education to the African Girl - Child: Suubi}

The hallmark of the second generation is the infiltration of formal education system into Africa. As per the expectation, there are numerous obstacles as African girls pursue education. Patriarchy seems to put a spirited fight to dissuade women from emancipating themselves through education. Thus women who acquire education must navigate the patriarchal obstacles.

The second generation women characters demonstrate the desire to avoid the passive characteristics demonstrated by Babirye and Nnakato. Rather they follow the precedence set by Zaya. They are represented by Suubi Nnakintu whose thirst for education is unquenchable. Suubi emergences, initially, as a girl under death threat as a result of starvation and epilepsy-like disease that she suffers from. A neighbour doesn't mince her words in foretelling her fate when her aunt, Kulata, complains: "If she is your blood... give her food while fate makes up her mind. Look at her: she looks half-dead already" (107). 
Our first encounter with Suubi paints a picture of desperate individual due to three aspects; her failing health, lack of somebody to love her, and starvation. She has been dumped at aunt Kulata's house in her absentia. Consequently, Kulata's attitude towards Suubi is supercilious. She reveals that Suubi's father, Waswa, hacked his twin brother - Kato - to death. Kulata's attitude is summarized in her explanation to neighbours:

The last I heard, this child was taken on by the grandmother, Waswa's mother, but as the saying goes: When it rains on a pauper, it does not allow his clothes to dry. The other day I heard the grandmother had also died and I said to myself, what kind of misfortune does that family have? I did not expect this child to be still alive. I mean, look at her (109).

Thus Suubi does not expect any kindness from her aunt. The only positive thing that Kulata does to Suubi which, ironically, is meant to be punitive is to take her to school: "The following day, Kulata took Suubi to Mother's Union Nursery School. She asked the teachers to keep her all day" (109). Suubi's landing in school marks the beginning of her self-glorification. She has to go through a lot of hurdles in pursuit of education. Firstly, she is threatened with prospects of being sacrificed by abductors who had offered to help her acquire a pair of shoes. She is only saved by the fact that she had pierced her eyes hence she wasn't "whole" for sacrifice. (127-130). Secondly, she is threatened with excommunication from the Palace by the landlady since aunt Kulata later finds herself under death threat after suffering from an incurable disease. The landlady, in an attempt to get rid of her, finds her a job as a house help. (133)

Such obstacles to education characterize the challenges that girls go though in pursuit of education. Where the environment is not conducive for early marriages, they are seen as potential house helps. On hesitating to agree to the deal, the landlady does not mince her words in informing her that she may not take up the job but the worst awaits her should her aunt die:

It is Ok, if you don't want to go, ... but I don't want to see you around my house except if you are living with your aunt. She dies, we pack you with her corpse on a truck and you will be taken to wherever she will be buried. You don't come back to my house. (133)

Such an obstacle can be construed to mean that Suubi's education is now coming to a halt. Her acceptance to go to work as a house help in Mr. and Mrs Kiyaga's home is informed by desire for security but it turns out to be an opportunity for her to acquire education and set herself free.

She joins Mr. Kiyaga's family with his wife Muwude and their three children: Katama, a boy of fifteen, Kulabato, a girl of fourteen, and Katiiti, a girl of ten. At first, she is treated as part of the family and allowed to sleep in the family's house with other children, until they accuse her of stealing from them. At this juncture, her education is threatened because Mr. Kayiga decides she should be taken to wherever she came from. Fortunately for her, aunt Kulata is dead and there being no other known relative, they have nowhere else to take her. They exchange bitter words regarding her continued stay:

'Didn't I say I wanted that girl to be removed when I left for work this morning?... I don't want her mixing with my children anymore. We now have three servants and that's enough. Besides, you know things have been disappearing since she arrived'. 'What do you want me to do,' now the wife's voice came from further in the house, 'throw her out on the streets? I took her back where I had found her but her aunt had died. She does not know her relations.' 'She is lying. Where did she come from? How can she not know where she came from?' 'Suubi was very young when she was abandoned and no one had seen any relations visiting. I can't just send her away; she is too young.' 'Then take her to the police.' 'And where will I say I found her?' (141).

The motherly approach by Mrs Kiyaga to Suubi's predicament coupled with the absence of any known relative saves her education. She, however, does not survive from being excommunicated from the main house. She is taken to the servant quarters. As fate would have it, she suffers from severe falciparum strain whereupon the family is forced to re-admit her to the main house, take her to hospital and be accommodative to her once more. Suubi's dream of acquiring education survives, stabilizing the metaphorical boat. Once she recovers, she goes back to school. The narrative goes:

One morning she woke up early and walked back to old Kampala Primary. She told the headmistress that she had been unwell and joined the primary seven class. At the end of the term when she brought home a fantastic school report, her parents could not believe that a child could walk for so many miles to school and still manage to study so well. 'Katama, Kula, Katiiti, look at this report!' Mummy said to Suubi's spoilt siblings (150).

Parents love a child who brings home a fantastic school report. Suubi gets celebrated for her good performance and is accommodated by the family on account of her resilience and determination. 
Though Suubi's case may be exceptional in terms of challenges she faces as an orphan and a sickly child, to a certain extent she represents the African girl child in pursuit of education at that point in time. The second generation of African women are exposed to challenges as they pursue education since they are not considered to be worthy it. They are meant to be prepared for marriage. The challenges that the girls undergo in her pursuit for education are, however, unique to the environment they find themselves in.

The later day Suubi that we meet eighteen years later is an emancipated mature person with good job and a boyfriend, Opolot, to boot. She is already an employed graduate from what we gather from the story that she relates to her boyfriend. She has fully been adopted by Kiyaga's family. She proudly informs her boyfriend: "My full name is Suubi N. Kiyaga. $N$ is for Nnakintu but I don't use it really. Nnakintu is the feminine version of Kintu" (158). When her foster father dies of stroke, there follows after burial rites for him. Suubi participates in it passively. Once the budget is set, she suggests that the children should contribute according to their means and goes ahead to give the highest amount. The celebration rites expose the readers to the character of each of Suubi's foster parents' children. The narrative goes:

However, while everyone else's contribution was met with approval, mine was met with stony silence yet it was quite substantial compared to everyone else's. You see, Kula, a teacher, is a single mother and Katiiti didn't have a man at the time. Katama doesn't part with money easily even though he is the eldest, the heir and the only son (161).

This elucidation allows the reader to see the financial superiority that characterizes the later day Suubi despite the challenges she faced in her initial stage of life. By virtue of contributing the highest amount, it means she is engaged in the highest paying job even above that of the heir of the family - Katama. The implication here is that there is already a significant systematic independence the second generation women are gaining as a result of acquiring education. Nevertheless, it is not blanket liberation as seen from the fact that it is conventional for Katiiti to be broke because "[she] didn't have a man at the time" (161).

Demonstratively, the second generation-women are presented with a choice; to either acquire education, secure a job and gain full independence or acquire education and still ascribe themselves to a man for financial support. However, it is evident that there is a humongous difference between the two generations' women. The passivity inherent in the first generation as well as total reliance on men for direction has been shed off. That a woman can choose to remain a single mother, rather than enter into a polygamous or loveless marriage marks the beginning of the manifestation of individual choice. Kula, a teacher, chooses the life of single motherhood. This can be juxtaposed against the desperation that characterized Babirye's parents when Kintu Kidda decided to marry Nnakato ahead of her. It was unheard of for a younger sister to be married ahead of her elder one let alone to fail to marry completely.

It is also worth noting that the patriarchs have considerably reduced the desire to demonstrate their macho. The power relationship between the two genders is like a see-saw. The African woman's literacy leading to financial and cognitive independence definitely challenges the gender hierarchy of power. The Kintu Kidda we meet among the first generation-women is, by all means, a representative of patriarchal dominance. His presence must be felt by women as a means of elevating patriarchy. Contrastingly, Katama of second generation does not attempt to make his patriarchal supremacy to be felt. The decision of how much money ought to be contributed is made by Suubi while he remains aloof. Failure to demonstrate his financial capability by taking up the duty of organizing for his late father's rites through directing what should be done and contributing more than the women involved is indicative of the metaphorical scale beginning to tilt in favour of the female gender. Thus the future of fully educated woman is prophesied as an undertaking that will lead to full liberation.

\section{$2 . .3$ Intertwining of Formal Education with Religion: Faisi}

The third generation-women characters feature Faisi, the wife of Kanani Kintu who is in the lineage of Kintu Kidda the patriarch of the pedigree. Numerous changes within the female fraternity have taken place since the times of Kintu Kidda the polygamous governor. The ideal patriarch as per the dictates of the pre-literate woman has been thoroughly reviewed, paving way for women to play key roles in the family set up. Christianity has also occupied central roles in the lives of some Africans hence diluting the effects of patriarchy. The Eurocentric culture that is packaged in both education and religion offers the female fraternity an opportunity to contest and re-define the culturally accepted practice of women's subjugation.

The couple who double as ardent preachers of the "Awakened" wing featured at this time in history; Faisi (The Ganda version of Faith) and Kanani (the Ganda version of Canaan) are, undoubtedly, at par in terms of privileges they enjoy both as missionaries of the Awakened wing of protestants and partners in the marriage institution. Even when Faisi proves to be a poor cook, Kanani can only make do with nostalgia of his mother's perfect cooking as he admires the freedom of cooking enjoyed by Mr. Lane a male missionary: 
In the 50s when he first joined the church administration, he envied European men who wandered in and out of the kitchen without restrictions. When missionaries invited him and Faisi to barbecues and dinners, Kanani saw white men help their wives cook. Some openly confessed their wives were hopeless cooks and that when they wanted a decent meal, they made it themselves. Yet, for him to let slip that Faisi was unimaginative in the kitchen was to undermine her as a woman (184).

The European culture that the Natives, especially the ones who have had an opportunity to interact closely with the missionaries, has had an effect in diluting the subjugation of women within the framework of patriarchy. Nevertheless, except in exceptional cases, the converts only acquired functional literacy which was heavily infused with religion. Thus Kanani's little education that helps him to read the Bible and preach stems from the fact that his mother was a missionary's housekeeper.

As pointed out earlier, the third generation women seem to have overshadowed the initial subjugation that always pushed them to the periphery. This has been achieved by aligning themselves with missionaries whose advocacy was for one to marry only one wife. The fact that Christianity was intertwined with European culture that seemed to have a check on patriarchy became a relief to the female fraternity especially those whose husbands converted to Christianity.

The sexist ideology responsible for male supremacy subdued is not fully subdued yet. Kanani's family exemplifies any other African family where parents over engage in other activities at the expense of offering proper parental guidance. Ruth and her twin brother Job involve themselves in incest resulting to pregnancy. Although done inadvertently, Job typifies phallocentric men that threatened the third generation women keen on acquiring education. Though African governments would later enact laws to safeguard the girl child against the prying eyes of men who exposed them to not only early pregnancy but also early marriage, the problem has not been fully arrested.

Notwithstanding that Ruth's pregnancy stems from incest which is uncommon among Africans, the act of the girl child dropping out of school to bring forth a child as the boy responsible for pregnancy continues with education is a manifestation of gendered injustice. While Ruth is exiled to aunt Bweeza's home at Nakaseke, Job continues with his education unimpeded. Many African girls who fall into early pregnancy trap don't go back to school. They, therefore, fall into waste even as their male counterparts proceed with education.

In this understanding, James Onyango opines that abolishing illiteracy has been top on the women's agenda for emancipation. Onyango, however, admits that in many patriarchal societies in Africa, educating a male child is more of a priority than educating a girl child (36). While some of these impediments to girl education may be circumstantial as is the case with Ruth, some African societies have tried to stick to the culture of women exclusivity hence making it difficult for them to acquire education.

Conclusively, despite the fact that Christianity and European culture acted as a major relief for moderating patriarchy, the perception of women as men's vessel of pleasure leading to early pregnancies and consequential dropping out of school characterize the third generation's African women. As a result, their education acquisition is a troubled one hence they are not yet at par with their male counterparts with in as far as education is concerned.

\subsection{Challenging the Patriarchal Dominance: Kusi Nnakintu}

Kusi Nnakintu a.k.a General Salamander, the fourth generation woman in Makumbi's novel Kintu is a prototype of a re-defined and re-packaged fourth generation women. She emerges as a total contrast to women of earlier generations - Nnakato and Babirye of the first generation, Suubi of the second generation and Faisi of the third generation who, seemingly, could not fully disentangle themselves from the shackles of patriarchy although they kept trying. The position of the fourth generation woman as a participant rather than an observer is strengthened by Magda Bweeza who later in the novel comes out as a strong contestant for clan leadership. The patriarch in this generation is Misirayimu Kintu, popularly known as Miisi, a Cambridge University educated PhD holder. The father of twelve children, he only has two remaining - Kamu Kintu and Kusi Nnakintu. He however has many grandchildren with whom he lives in his mansion in the village. In apparent dramatic irony, the audience know that Kamu Kintu's body is sleeping in state at the mortuary after being murdered by mob justice on suspicion of stealing musical equipment - 5CD Sony stereo player and Panasonic TV (xvii) but the father and daughter are not aware. Practically, therefore, Miisi's only surviving child is Kusi Nnakintu popularly known as General Salamander.

The practice of choosing what profession for daughters and generally directing their life is no longer tenable among the contemporary generations. Moreover, the contemporary women appear determined to take up the jobs that were a preserve of the male child therefore breaking from the societal norm where women are taught to stick to what the society considers conventional for them. General Salamander has voluntarily chosen the life of the jungle. In the process, she has risen through the ranks to become a general thus she has men under her command, some as members of her platoon and others as her body guards (363). 
Owing to her choice, Kusi occupies a very significant position both in her family and her country. After most of other Miisi's children are killed by either HIV/AIDS or the war, she turns out to be the provider of the family. When she comes to visit her father, she comes home carrying so much food stuffs that her father is forced to invite the household to come and witness her providence: "come everyone, come and see what my girl has done" (364). Thus her "masculinity" is celebrated rather than being frowned upon by her father. Tellingly, Kusi's choice of a respectable profession anchored by her elevation to a senior position where she has men at her disposal to serve her almost promotes her to the position of a man. Her father's remark and the author's comment demonstrate this elevation: "we have something important to talk about" Miisi told her sister as if Kusi was a son and they were going to have manly whispers (my emphasis, 265). Evidently, it is the choice that Kusi has made that earns her such respect from her father in particular and the country in general. She explains to her father that she has been busy in the Northern part of the country trying to suppress Kony's rebellion, an important undertaking in the effort to ensure the country remains stable. She has thus positioned herself as the provider of the family and the protector of the state, a common masculine occupation by the dictates of patriarchy.

Remarkably, the tough choice that contemporary women make does not ostracize them from their femininity characteristics. Despite all her accomplishments, her father feels that her childlessness is a void that she needs to fill. During their meeting, her father asks her emphatically when she is going to have a child. To recognize her position, Miisi makes it clear that as far as he is concerned, her status places her above marriage. Miisi explains: "I am not asking you to get married. I would not inflict on you any man, I am only asking for a child... I am asking for yours, at least one" (365). Thus, despite contemporary women making choices that put them, arguably, beyond marriage, the societal expectation does not occlude them from continuing the process of procreation. Thus, the author in a subtle manner supports the contemporary woman's self-elevation through choosing hitherto the masculine profession but hints at the need not to forget the duties that nature rather than patriarchy prescribes for women.

\section{Conclusion}

The history of African gender interrelationship as portrayed by African women writers who choose to take the audience through century-long generational setting is an exciting journey characterized by female gender metamorphosis from victimhood to emancipation. The first-generation pre-literate women represented by Nnakato and Babirye are prototype of a subdued woman who has no voice to question the dictates of patriarchy. Through Zaya's refusal to be commanded around, however, the author foretells the beginning of liberalization. The second generation is characterized by beginning of embracing formal education among African women and an attempt by the patriarchs to put obstacles on the paths of women in order to maintain the status quo. Women such as Suubi, however, negotiate the obstacles to acquire education and consequently get a considerable amount of freedom. The third generation represented by Faith (Faisi) demonstrates total intertwining of religion and formal education. The missionaries have managed to "civilize" Africans hence watering down the effects of African patriarchs. Faisi is more of a helper to her husband rather than a victim of patriarchy. Lastly, the fourth generation, the contemporary woman is fully emancipated. Kusi a.k.a General Salamander is in a position to make her own choice on which job she wishes. She is also the provider of the family and the heir apparent. Marriage to her is a choice that she can make. Indeed, the African woman has travelled a worthy journey through obstacles but has, seemingly, been liberalized.

\section{References}

[1] Azumara, S. O. (2010). Marxism and African Literature: Commodification and Ideological Conditioning in Achebe's "Things Fall Apart". Lagos Papers in English, 12, 12-29.

[2] Brannigan, J. 1998. New Historicism and Cultural Materialism: Routledge Daymond.

[3] Gallagher, C. and Stephen G. 2001. Practicing New Historicism: University of Chicago Press Hanrahan, R. and Antony, L. 2005. Because I Said So: Toward A Feminist Theory of Authority. Hypatia, 22 (4), 59-79

[4] Kennedy, R. (2000). Feminist Literary Theory. In L. Code (Ed.), Encyclopaedia of Feminist: Routledge

[5] Lihamba, A., Fulata L., Mugyabuso M. Mulokozi and Naomi, S. (2007). Eds. Women Writing Africa: Vol.3 (The Eastern Region). New York: Feminist.Press at CUNY

[6] Makumbi, J. (2014). Kintu, Kenya: Kwani? Trust Mule, K. 2007. Women's Spaces, Women's Visions: Politics, Poetics, and Resistance in African Women's Drama: Africa World Press

[7] Onyango, O. (20060. Dark Shadow of Masculinities and Women Emancipation Agenda. Younde: CODESRIA. 1\&2: 36

[8] Sadiqi, F., Amira N., Azza K. and Moha E. (2003). Eds. Women WritingAfrica: Vol.4 (The Nothern Region): Feminist Press at CUNY

[9] Stratton, F. (1994). Contemporary African Literature and Politics of Gender. Routledge

[10] Sutherland-Addy E. and Aminata D., (2005). Eds. Women Writing Africa: Vol.2 (West Africa and the Sahel): Feminist Press at CUNY

[11] Tamale, S. (1999). When Hens begin to Crow: Gender and Parliamentary Politics in Uganda. Westview Press: 218 - 230 